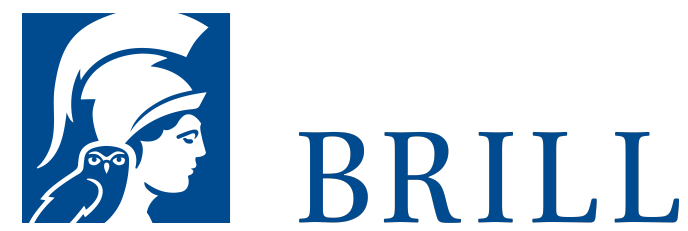

\title{
Western Esotericism in Scandinavia
}

Volume Editors: Henrik Bogdan and Olav Hammer

This is the first encyclopaedic work on Western esotericism in Scandinavia. Structured along the lines of the Dictionary of Gnosis and Western Esotericsm (2005), it contains over 80 articles written by 47 specialists. It consists of critical overviews of all the major esoteric currents in Denmark, Finland, Norway, and Sweden, ranging from Alchemy, Anthroposophy, and Astrology, to Theosophy, Traditionalism, and UFO Movements. This ground-breaking work is of relevance not only for scholars and students of Western esotericism, but for all with an interest in alternative religious traditions and Scandinavian intellectual history.

\section{Readership}

Academic libraries and all interested in Western esotericism, history of religions and alternative religious traditions, and anyone interested in religion in Scandinavia.

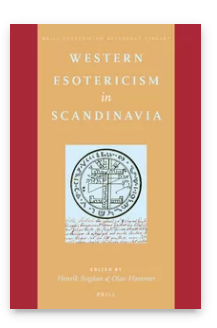

Language:

English

Subjects:

Sociology of

Religion,

Religious

Studies, Religion

\& Society, Social

Sciences,

Modern History,

History

Publisher: Brill

Series:

Brill Esotericism

Reference

Library

E-Book (PDF)

Released online:

21 Jun 2016

ISBN: 978-90-

04-32596-8

List price

USD \$287.00

Hardback

Publication date:

31 Mar 2016

ISBN: 978-90-

04-30241-9

List price

USD $\$ 287.00$ 
Henrik Bogdan is Associate Professor in Religious Studies at the University of Gothenburg. He is the author and co-editor of several works, including Handbook of Freemasonry (Brill, 2014, co-edited with J.A.M. Snoek).

Olav Hammer is Professor in the Study of Religions at the University of Southern Denmark. He has published numerous works, including the Handbook of the Theosophical Current (Brill, 2014, co-edited with Mikael Rothstein).

Contributors are: Søren Bak-Jensen, Kristian Bjørkelo, Henrik Bogdan, Robert Carleson, Jenny-Ann Brodin Danell, Gina Dahl, Asbjørn Dyrendal, Carl-Michael Edenborg, Morten Fink-Jensen, Liselotte Frisk, Susanne Gieser, Ingvild Gilhus, Kennet Granholm, Fredrik Gregorius, Olav Hammer, Jan-Erik Ebbestad Hansen, Jan Bertil Heilund, Titus Hjelm, Nils G. Holm, Thomas Karlsson, Siv-Ellen Kraft, Jesper Kragh, Håkan Lejon, Kjell Lekeby, Fabian Linde, Kjersti Løken, Tomas Mansikka, Tonje Mehren, Kirstine Munk, Jaakko Närvä, René Dybdal Pedersen, Benjamin Weber Pedersen, Jonathan Peste, Einar Petander, Jesper Aagaard Petersen, Mikael Rothstein, Jacob Senholt, Jole Shackelford, Tom Sjöblom, Jussi Sohlberg, Sara Thejls, Søren Feldtfos Thomsen, Geir Uldal, Jane Williams-Hogan, Geir Winje, Susanna Åkerman, and Andreas Önnerfors.

For more information see brill.com

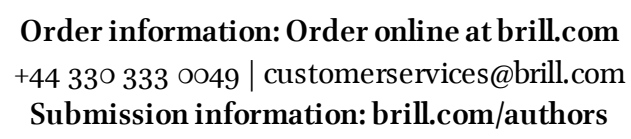

